\title{
Antinociceptive and Anti-inflammatory Effects of Methanolic Extract of Laurencia caspica
}

\author{
Katayoon Karimzadeh ${ }^{1 *}$, Mahdiyeh Ramzanpoor ${ }^{1}$,Shadi Keihankhadiv ${ }^{2}$ \\ 'Department of Biology, Lahijan Branch, Islamic Azad University, Lahijan, Iran. \\ ${ }^{2}$ Department of Chemistry, Pharmaceutical Sciences Branch, Islamic Azad University, Tehran, Iran.
}

\author{
*Correspondence to \\ Katayoon Karimzadeh, \\ Email: karimzadehkathy@yahoo. \\ co.uk
}

Received July 5, 2019 Accepted December 18, 2019 Published online June 30, 2020

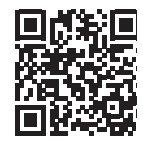

\section{Please cite this article} as follows: Karimzadeh K, Ramzanpoor M, Keihankhadiv S. Antinociceptive and Anti-inflammatory Effects of Methanolic Extract of Laurencia caspica. Int J Basic Sci Med. 2020;5(2):5460. doi:10.34172/ ijbms.2020.11.

\begin{abstract}
Introduction: Seaweeds are valuable resources for the discovery of efficient and safe drugs for pain treatment. In the present investigation, we evaluated the antinociceptive and antiinflammatory properties of, methanolic extract of Laurencia caspica, a red algae, in mice models. Methods: The analgesic effect of methanolic extract of $L$. caspica was assessed by hot-plate and acetic acid-induced writhing tests in male Swiss albino mice (weight=20-25 g). The antiinflammatory activity of methanolic extract of $L$. caspica was also evaluated by formalin-induced ear edema and xylene-induced paw edema tests.

Results: The total flavonoid content of the extract was estimated as $0.0537 \mathrm{mg}$ quercetin $/ \mathrm{g}$ extract. Both first and second phases of the nociception were significantly inhibited at a dose of $120 \mathrm{mg} / \mathrm{kg}$ of methanolic extract of L. caspica. The observed anti-inflammatory effect was dose-dependent. Acetic acid-induced writhing test and hot plate test showed that the extract significantly reduced pain in all evaluated doses $(15,30,60$, and $120 \mathrm{mg} / \mathrm{kg})$. The antinociceptive activity of the methanolic extract was significantly reduced by naloxone ( $4 \mathrm{mg} / \mathrm{kg}$ ). Moreover, the extract significantly reduced paw edema at the dose of $120 \mathrm{mg} / \mathrm{kg}$ in all the animals.

Conclusion: Methanolic extract of L. caspica exhibited central analgesic effect, as well as anti-inflammatory activity probably due to the presence of constituents like flavonoids and triterpenoids.

Keywords: Red algae, Laurencia caspica, Anti-inflammatory, Antinociceptive
\end{abstract}

\section{Introduction}

The aquatic ecosystem is considered a rich source of natural products with extensive therapeutic applications. ${ }^{1}$ Marine products, especially those derived from the secondary metabolism of marine organisms, are accepted as a potential source of pharmaceuticals for the management of various diseases. ${ }^{2}$ Seaweeds consist of three phyla including green, red, and brown algae, and three families including Chlorophyceae, Rhodophyceae, and Phaeophycea. The red algae or Rhodophyceae are major algae groups in bioactive compounds due to their potential pharmacological properties like antimicrobial, antioxidant, anticancer, analgesic, and anti-inflammatory effects. ${ }^{1,3}$ Bioactive compounds with free radical scavenging potential have been able to harness any reactive oxygen species. ${ }^{4}$ Endothelial dysfunction, ${ }^{5}$ lung disease, ${ }^{6}$ gastrointestinal disorder, ${ }^{7}$ and atherosclerosis ${ }^{4}$ can permute inflammatory reactions due to oxidative stress. Some marine algae metabolites, which hold antioxidant effects, are known to have antiinflammatory properties as well. ${ }^{8-10}$

The inflammation can be regarded as a set of complicated processes including defensive responses of organisms to antigenic stimulation or injuries. ${ }^{11,12}$ The inflammation, especially the chronic type, is also a common complication of many diseases and leads to weakness of the immune system. Furthermore, it is the pathophysiological response of healthy tissues to injured tissues that leads to the local accumulation of plasma proteins and blood cells. Anti-inflammatory agents could treat pain by inhibiting the production of prostaglandins through blocking the enzyme cyclooxygenase (COX). ${ }^{13,14}$

Pain is a protective mechanism that can be the result of an acute or a chronic lesion. ${ }^{14}$ Pain can be categorized as either acute or

(c) 2020 The Author(s); Published by Zabol University of Medical Sciences. This is an open-access article distributed under the terms of the Creative Commons Attribution License (http://creativecommons.org/licenses/by/4.0), which permits unrestricted use, distribution, and reproduction in any medium, provided the original work is properly cited. 
chronic. Acute pain involves a warning mechanism in tissue damages and may be caused by many events or circumstances. While chronic pain is an independent and complex entity that seriously affects patients' life quality and thus is considered an illness. ${ }^{15,16}$ Prostaglandins made by COX-2 can cause pain by binding to receptors associated with $\mathrm{G}$ proteins and increasing cAMP level in cells. ${ }^{17,18}$ The pain relievers and anti-inflammatory drugs are classified into opioid analgesics (e.g., enkephalin, endorphin, morphine, and methadone) and nonsteroidal anti-inflammatory drugs (NSAIDs) like aspirin and acetaminophen. Moreover, some NSAIDs have so much side effects that often lead to drug discontinuation. Increased risk of digestive, cardiovascular, and renal diseases and drug-related morbidity are regarded as important symptoms of long-term use of these drugs. ${ }^{15}$ Accordingly, finding new natural products with antiinflammatory effects without any side effects is an important issue. In this regard, during the past decades, herbal drugs have been the subject of interest because of their pharmacological effects. ${ }^{18,19}$

Laurencia caspica (red macro algae) is an important seaweed that grows in the southern coast of the Caspian Sea. ${ }^{19}$ The phytochemistry of Laurencia species has been attributed to the large amounts of various halogenated secondary metabolites such as diterpenes, halogenated sesquiterpenes, and acetogenins produced by these genera. ${ }^{20}$ Some studies have demonstrated that the secondary metabolites from the red alga have potential effects such as anti-inflammatory, anti-cancer, and analgesic activities. ${ }^{20-22}$ The anti-inflammatory activity of red algae, L. glandulifera and L. obtuse, in previous studies have been reported. ${ }^{23,24}$ As there is no report on the antiinflammatory activity of $L$. caspica to the best of our knowledge, the objective of current work was to evaluate the effect of methanolic extract of L. caspica on pain and inflammation in mice.

\section{Materials and Methods \\ Chemicals}

Glacial acetic acid-xylene was purchased from SigmaAldrich (Germany). Formalin was obtained from Merck Co. (Darmstadt, Germany). Aspirin used as the reference was also purchased from Iran Daru Co., Tehran, Iran.

\section{Sample Collection and Extract Preparation}

Laurencia caspica, the red algae samples, were collected from Ramsar beaches, Caspian Sea, Mazandran, Iran, in May 2015, and transferred within a plastic bag to the Biotechnology Laboratory of Islamic Azad University. The samples were identified according to a study by Sterrer. ${ }^{25}$ First, the algae were washed thoroughly to be completely free of sand and epiphytic organisms and were immersed in distilled water to remove salts. Then, the specimens were spread over a clean and sterile cloth in shadow for three days to dry. In the next step, the samples were completely powdered by grinding using a blender (Waring, USA).

Dried red alga powder (100 g) was dissolved and soaked in $500 \mathrm{~mL}$ of methanol for 10 hours at room temperature. ${ }^{15}$ The extract was concentrated to a suitable volume using rotary evaporator (Model: WG-EV311-V-PLUS, USA).

\section{Total Phenolic Content Assessment}

Total flavonoid content was measured using FolinCiocalteu reagent according to a modified method of Ainsworth. ${ }^{26}$ The methanolic extract of red algae (0.5 $\mathrm{mL}$ ) was mixed with $2 \mathrm{~mL}$ of the Folin-Ciocalteu reagent. Then the sodium carbonate solution, $7.5 \% \mathrm{w} / \mathrm{v}(4 \mathrm{~mL})$, was added. After incubation at room temperature for 30 minutes, the absorbance of the solution was measured at $765 \mathrm{~nm}$ using UV-visible spectrophotometer (Jenwey, UK). The total phenolic content was calculated from the linear equation of a standard curve determined with gallic acid $(Y=0.008 \mathrm{X}+0.0727, R 2=0.9967)$. The result was estimated as $\mathrm{mg} / \mathrm{g}$ gallic acid equivalent of dry extract.

\section{Animals}

Male Swiss mice (20-25 g) applied in this work were provided by the Animal House of Pasteur Institute, Karaj, Iran, and preserved in proper hygienic conditions at the Animal House of Islamic Azad University, Lahijan Branch, Iran. The animals were acclimatized for one week to the experimental conditions in ventilated plastic cages at $22^{\circ} \mathrm{C}$ with a relative humidity of $45 \%-50 \%$, under a 12 hour light/dark cycle. Animals were fed with laboratory chow and water ad libitum. To do the experiment, animals were randomly assigned into 6 groups and deprived of food and water.

\section{Acute Toxicity Study}

For acute toxicity, Swiss mice were categorized into different groups $(\mathrm{n}=6)$, and intraperitoneally administered with different doses (25, 200, and $2000 \mathrm{mg} /$ $\mathrm{kg}$ ) of L. caspica extract. The animals were monitored for 72 hours for any toxic signs and mortality. ${ }^{27}$

\section{Drug Administration}

The animals were categorized into six groups $(n=8)$. Group I received normal saline. Group II, served as positive control, received dexamethasone $(15 \mathrm{mg} / \mathrm{kg})$ for formalin and xylene tests. Morphine $(10 \mathrm{mg} / \mathrm{kg})$ was injected for the induction of paw edema. Group III, group $\mathrm{IV}$, group V, and group VI received 15, 30, 60, $120 \mathrm{mg} / \mathrm{kg}$ of the methanolic extract of L. caspica, as the treatment groups, respectively.

\section{Formalin Test}

The formalin paw assay was carried out as reported by Hunskaar et al. $^{28}$ The animals in each test group acclimatized for 30 minutes before the experiment and then intraperitoneally received extract at doses of 15, 30, 
60, and $120 \mathrm{mg} / \mathrm{kg}$. Paw edema was induced in mice by injection of $25 \mu \mathrm{L}$ formalin $5 \%$ into the plantar side of right hind paw 30 minutes after injection of methanolic extract, dexamethasone, and normal saline. The time spent for licking and biting the injected paw was taken as behavioral response to pain and was recorded for each group. After formalin injection, responses were observed for 5 minutes and 20-30 minutes, respectively.

\section{Xylene-Induced Ear Edema Test in Mice}

The xylene test was performed using the procedure described by Shang et al. ${ }^{29}$ The ear edema was induced by application of xylene $(30 \mu \mathrm{L} / \mathrm{ear})$ on the right ear. Animals receiving different doses of methanolic extract $(15,30,60$, and $120 \mathrm{mg} / \mathrm{kg}$ i.p. $)$, either received $10 \mathrm{mg} /$ $\mathrm{kg}$ morphine as a positive control or normal saline (10 $\mathrm{mL}$ ) as a negative control. Fifteen minutes after injection, mouse ear edema was induced by the topical application of $30 \mu \mathrm{L} /$ ear of xylene. Two hours after xylene daubing, the mice were euthanized. Two ear punches were taken from each mouse and weighed. The edema was indicated by a rise in the weight of right ear punch compared to that of the left ear.

\section{Hot Plate Test}

This test was done according to a reported assay. ${ }^{30}$ The hot plate apparatus was set at $54 \pm 0.1^{\circ} \mathrm{C}$ and the mice were put on the hot surface. The pain response latency was measured based on the time elapsed between placement and licking of their hind paws. After recording the baseline reaction (cut off $=45$ seconds), the animals were intraperitoneally (i.p.) administered with normal saline $(10 \mathrm{~mL} / \mathrm{kg})$ as the negative control, morphine $(8 \mathrm{mg} / \mathrm{kg})$ as the positive control, and L. caspica extract at 4 doses (15, 30,60 , and $120 \mathrm{mg} / \mathrm{kg}$ ). The reaction time to hot plate was observed at $0,15,30,45$, and 60 minutes after injection. The results are summarized in Table 1 and the maximum possible effect (MPE) percentage was measured using the following formula to find the time with maximum nociceptive effect:

$\operatorname{MPE}(\%)=($ Test latency- baseline latency $) \times 100 /$ (cut offbaseline latency)

\section{Acetic Acid-Induced Writhing Test}

The acetic-induced writhing test was conducted according to the method reported by Aoki et al. ${ }^{30}$ Experimental groups were administered with $15,30,60$, and $120 \mathrm{mg} /$ $\mathrm{kg}$ of methanolic extracts of $L$. caspica. In addition, morphine $(10 \mathrm{mg} / \mathrm{kg})$ and normal saline $(10 \mathrm{~mL} / \mathrm{kg})$ were administered to the positive and negative control groups, respectively. The animals were administered with an intraperitoneal injection of $0.1 \mathrm{~mL} / 10 \mathrm{~g}$ body weight acetic acid (0.7\%). The abdominal constrictions during 30 minutes after acetic acid injection were measured. Animals pretreated with morphine (5 mg/kg, p.o.) were used as positive control. To evaluate the possible involvement of the opioid system in the antinociceptive activity of the algae extract, naloxone $(4 \mathrm{mg} / \mathrm{kg}$, i.p.) was injected 15 minutes before the administration of the extract (120 mg/kg, p.o.) or morphine (5 mg/kg, p.o.) to each group of animals. The frequency of constrictions for each concentration versus the normal saline control was applied for estimating the analgesic activity. The amount of inhibition of writhing was calculated using the following equation:

Inhibition $(\%)=\left[\left(\right.\right.$ mean writhing ${ }_{\text {control }}-$ mean writhing treated $) /$ mean writhing $\left.{ }_{\text {control }}\right] \times 100$

\section{Statistical Analysis}

All data were represented as the mean \pm SEM $(n=8$ per group). Statistical analyses were performed by SPSS software version 19.0, and the results were analyzed by one-way analysis of variance (ANOVA) followed by the post hoc analysis using Tukey's test. A value of $P<0.05$ was taken as the level of significance.

Table 1. Effects of Intraperitoneal Injection of Methanolic Extract of Laurencia caspica on Acute and Chronic Pain Revealed by Formalin Test

\begin{tabular}{|c|c|c|c|c|}
\hline Drug (mg/kg) & & Nociceptive Phase & Licking Time (s) & Inhibition of Nociception (\%) \\
\hline \multirow{2}{*}{\multicolumn{2}{|c|}{ Control (normal saline) }} & Acute & $74.65 \pm 2.127$ & - \\
\hline & & Chronic & $216.54 \pm 32.14$ & - \\
\hline \multirow{2}{*}{\multicolumn{2}{|c|}{ Morphine (5) }} & Acute & $28.05 \pm 1.582^{\mathrm{a}}$ & 79.45 \\
\hline & & Chronic & $36.40 \pm 5.201^{\mathrm{c}}$ & 86.86 \\
\hline \multirow{2}{*}{\multicolumn{2}{|c|}{ Indomethacin (10) }} & Acute & $74.40 \pm 6.005$ & 0.61 \\
\hline & & Chronic & $4.65 \pm 3.107^{c}$ & 0.52 \\
\hline \multirow{8}{*}{ Methanolic extract $(\mathrm{mg} / \mathrm{kg})$} & \multirow{2}{*}{15} & Acute & $71.02 \pm 1.085$ & 0.61 \\
\hline & & Chronic & $135.71 \pm 2.423^{\mathrm{a}}$ & 0.52 \\
\hline & \multirow{2}{*}{30} & Acute & $65.46 \pm 2.54$ & 17.86 \\
\hline & & Chronic & $87.15 \pm 4.314^{\mathrm{b}}$ & 7.34 \\
\hline & \multirow{2}{*}{60} & Acute & $50.61 \pm 3.22^{\mathrm{a}}$ & 62.93 \\
\hline & & Chronic & $42.11 \pm 1.173^{\mathrm{c}}$ & 54.55 \\
\hline & \multirow{2}{*}{120} & Acute & $33.04 \pm 1.14^{\mathrm{a}}$ & 77.26 \\
\hline & & Chronic & $25.63 \pm 1.388^{c}$ & 83.53 \\
\hline
\end{tabular}

Results have been shown as mean \pm SEM in seconds $(n=7)$

${ }^{\text {a }} P<0.05,{ }^{\text {b }} P<0.001$; ${ }^{\mathrm{c}} P<0.0001$ compared to the control group. 


\section{Results}

Total flavonoid content of the methanolic extract was calculated to be about $0.0537 \mathrm{mg}$ of quercetin/g extract. The latencies after injection (baseline latency) were analyzed by the ANOVA; no significant difference was seen between the test and control groups. No mortality was observed after 72 hours in animals administered with different concentrations of extract. Moreover, no toxicity signs were observed in treated groups at 25 and $200 \mathrm{mg}$ / $\mathrm{kg}$. But, the sedative effect was shown at a dose of 2000 $\mathrm{mg} / \mathrm{kg}$.

\section{Formalin Test}

The test revealed that the maximum dosage (120 mg/kg) of methanolic extract in both phases (acute and chronic) can mitigate pain significantly $(P<0.05)$. As can be seen, there was no difference regarding morphine response between two phases $(79.45 \%$ and $86.86 \%$ in acute and chronic, respectively). Moreover, all dosages of the methanolic extract of L. caspica inhibited pain at the acute phase compared to the control.

\section{Xylene Test}

The anti-inflammatory effect of intraperitoneal injection of the methanolic extract on xylene-induced ear edema is illustrated in Table 2. The xylene-induced ear edema decreased significantly in the treatment group compared to the control group. A dose-dependent manner was observed in inhibition of the edema. Hence, the maximum inhibition was measured at a dose of $120 \mathrm{mg}$ / $\mathrm{kg}$, which was significantly different from the other doses of methanolic extract and control $(P<0.05)$.

\section{Hot Plate Test}

After injection, the latencies were analyzed though

Table 2. The Effect of Intraperitoneal Administration of Methanolic Extract of Laurencia caspica on Xylene-Induced Ear Edema in Mice

\begin{tabular}{lccc}
\hline Treatment & Dose $(\mathbf{m g} / \mathbf{k g})$ & $\begin{array}{c}\text { Weight Gain } \\
\text { of Ear }(\mathbf{m g})\end{array}$ & $\begin{array}{c}\text { Percentage } \\
\text { of Inhibition } \\
(\%)\end{array}$ \\
\hline Control & Normal saline & $15.2 \pm 0.35$ & \\
& 15 & $13.2 \pm 0.24$ & 13 \\
L. caspica extract & 30 & $12.6 \pm 0.15^{\mathrm{a}}$ & 17 \\
& 60 & $11.1 \pm 0.38^{\mathrm{a}}$ & 27 \\
Dexamethasone 15 & Dexamethasone 15 & $6.46 \pm 0.28^{\mathrm{b}}$ & 57 \\
\hline
\end{tabular}

a $P<0.05 ;{ }^{\text {b }} P<0.01$ compared to negative control. no significant difference was observed between the treatment and control groups. The maximum efficacy was determined at $15 \mathrm{mg} / \mathrm{kg}$ of methanolic extract after 30 minutes. Response latency in different groups has been summarized in Table 3. Considering MPE, the most effective dose was observed at 30 minutes after extract injection (Figure 1).

\section{Acetic Acid-Induced Writhing Test}

The writhing test was used for the evaluation of antinociceptive activity of methanolic extract of L. caspica. The pain induced by acetic acid in mice was reduced in all groups treated with methanolic extract.

The frequency of writhing was significantly different in all treatment groups in comparison with the control group $(P<0.05)$. The concentration of $120 \mathrm{mg} / \mathrm{kg}$ was indicated in the least writhing number $(9.8 \pm 1.44)$ with $70.8 \%$ inhibition. The results have been presented in Table 4. Morphine $(5 \mathrm{mg} / \mathrm{kg})$ as the reference drug showed significant protective effects $(P<0.001)$. Prior administration of naloxone significantly increased the number of abdominal writhing in both morphine $(P<0.001)$ and the extract $(P<0.01)$ treated mice. The dose-dependent manner was observed in the reduction of pain induced by acetic acid. Among all tested groups, the dose of $120 \mathrm{mg} / \mathrm{kg}$ had a significant impact on pain relief compared to the control and the reference drug (naloxone) $(P<0.05)$.

\section{Discussion}

Intensive investigations have been directed on the treatment of pain. Plant extracts and their isolated natural compounds have been greatly applied for their pain reducing properties. During the last decade, the pharmaceutical market, based on phyto-therapeutics, has grown dramatically duo to increasing demand around the world. Recently, natural marine products have attracted a great attention as they have provided new perspectives for novel pharmaceutics, which are unlike any found on the ground. ${ }^{31}$

The methanolic extract of L. caspica demonstrated the antinociceptive activity in acute and chronic phases, where the greatest analgesic effect in both phases was attributed to dose $120 \mathrm{mg} / \mathrm{kg}$. Furthermore, the analgesic impact was confirmed in a dose-dependent manner in the formalin and writhing tests. In xylene test, it was observed

Table 3. Response Latency Observed by Hot Plate Test in Mice Groups $(n=7)$

\begin{tabular}{|c|c|c|c|c|c|}
\hline \multirow{2}{*}{ Treatment (mg/kg) } & \multicolumn{5}{|c|}{ Latency (s) } \\
\hline & $\mathbf{0}$ & 15 & 30 & 45 & 60 \\
\hline Control & $8.64 \pm 1.50$ & $10.20 \pm 2.30$ & $10.6 \pm 7.30$ & $9.3 \pm 2.44$ & $7.9 \pm 2.50$ \\
\hline Morphine & $9.32 \pm 1.80$ & $13.45 \pm 3.60^{\mathrm{a}}$ & $15.73 \pm 4.30^{b}$ & $14.99 \pm 2.60^{b}$ & $13.3 \pm 4.00^{\mathrm{a}}$ \\
\hline 15 & $8.42 \pm 1.49$ & $12.53 \pm 3.27^{\mathrm{a}}$ & $17.33 \pm 4.46^{\mathrm{b}}$ & $12.92 \pm 3.80^{\mathrm{a}}$ & $9.41 \pm 2.60$ \\
\hline 30 & $8.73 \pm 2.65$ & $13.16 \pm 1.14^{a}$ & $13.36 \pm 1.11^{\mathrm{a}}$ & $13.04 \pm 2.17^{\mathrm{a}}$ & $9.8 \pm 1.27$ \\
\hline 60 & $8.95 \pm 2.56$ & $13.16 \pm 1.62^{\mathrm{a}}$ & $13.30 \pm 1.15^{\mathrm{a}}$ & $13.01 \pm 2.17^{\mathrm{a}}$ & $11.3 \pm 2.56$ \\
\hline 120 & $9.14 \pm 1.14$ & $13.20 \pm 2.42^{\mathrm{a}}$ & $13.44 \pm 3.21^{\mathrm{a}}$ & $13.22 \pm 3.48^{\mathrm{a}}$ & $12.6 \pm 2.72$ \\
\hline
\end{tabular}




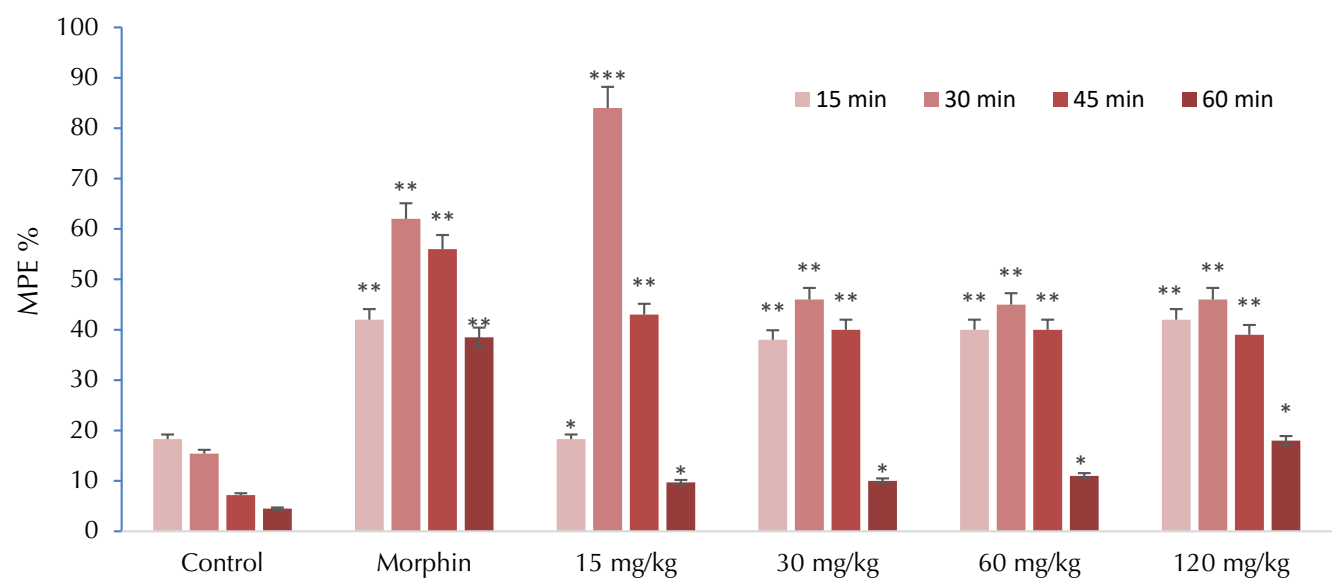

Figure 1. The Maximum Possible Effect (\%MPE) of Acute Pain Inhibition at Different Time Points in Hot Plate Test $(\mathrm{n}=7) .{ }^{*} P<0.05 ;{ }^{* *} P<0.01$ compared to negative control.

that all treatment doses had an anti-inflammatory effect, with the highest impact seen at the maximum dose of extract (i.e., $120 \mathrm{mg} / \mathrm{kg}$ ). It was proposed that the antiinflammatory property of methanolic extract can be due to the inhibition of enzymes such as COX and lipoxygenase, which importantly act in arachidonic acid metabolism..$^{32,33}$ Lactonic and phenolic compounds, flavonoids, fatty compounds, triterpenes, steroids, reduced carbohydrates, and other sugars have been the main ingredients of red algae, Dichotomaria obtusata. ${ }^{15}$ Among phytochemical compounds, flavonoids are natural polyphenol compounds that can inhibit nitric oxide (NO) synthase enzyme. Flavonoids are able to inhibit N-methyl $\mathrm{D}$-aspartate receptors and reduce the intracellular calcium level. Consequently, the calcium-dependent activation of NO synthase and phospholipase A2 is diminished. In addition, flavonoids could inhibit the activity of COX so that the production of prostaglandin $\mathrm{E}$ from arachidonic acid is prevented. Regarding the fact that prostaglandins play a role in inflammation, it is suggested that the red algae flavonoids exert anti-inflammatory effects. ${ }^{33,34}$

It is proposed that the terpenoids isolated from red algae $L$. dendroidea inhibit cell proliferation, inflammation, and metastasis. ${ }^{1}$ The anti-inflammatory

Table 4. Effect of Methanolic Extract of Laurencia caspica on Acetic AcidInduced Abdominal Writhing Test in Mice

\begin{tabular}{lcc}
\hline Treatment & Dose $(\mathbf{m g} / \mathbf{k g})$ & Number of writhing \\
\hline Control & Normal saline & $31.6 .00 \pm 1.07$ \\
& 15 & $21.4 \pm 3.70^{\mathrm{a}}$ \\
L. caspica extract & 30 & $17.5 \pm 2.24^{\mathrm{a}}$ \\
& 60 & $9.2 \pm 2.13^{\mathrm{a}}$ \\
Morphine & 120 & $9.8 \pm 1.44^{\mathrm{a}}$ \\
Morphine/naloxone & 5 & $19.32 \pm 1.71^{\mathrm{b}}$ \\
Extract/naloxone & $5 / 4$ & $34.12 \pm 2.84^{\mathrm{c}}$ \\
\hline
\end{tabular}

Results have been indicated as mean \pm SEM; $(n=7)$.

${ }^{a} P<0.001$ compared to the control group; ${ }^{b} P<0.001$ compared to the group receiving morphine; ${ }^{c} P<0.01$ compared to the group receiving extract (120 $\mathrm{mg} / \mathrm{kg}$ ). effects of L. glandulifera are explained by the presence of neorogioltriol, which is a tricyclic brominated diterpenoid. ${ }^{23}$ This compound influences acute and chronic phases of inflammation via the effect on signaling pathways including nuclear factor- $\kappa \mathrm{B}(\mathrm{NF}-\kappa \mathrm{B}) .{ }^{35}$ Studies on red algae have demonstrated that terpenoids from red algae L. obtuse have anti-inflammatory properties. ${ }^{24}$ The antiinflammatory effects of red algae L. obtuse are different from those of C15 acetogenins (12Z)-cis-maneonene-D and (12E)-cis-maneonene-E. During inflammatory responses, the significant role of these components in mediating apoptosis of neutrophils has been proved. ${ }^{24,36}$

The methanolic extract of $L$. caspica significantly reduced the licking episodes in the injected paw in a dose-dependent manner. This result indicated that the antinociceptive property of the algae extract may contribute to the treatment of chronic pain. ${ }^{31}$ Writhing test is another test model that was used for screening antinociceptive action. In this test, abdominal constriction is induced by acetic acid by inducing endogenous mediators and stimulating the pain nerve endings. ${ }^{37-39}$ The methanolic extract represented significant inhibition on acetic acid-induced writhing response. The hot plate test is used for central antinociceptive effect on animal models like mice. ${ }^{40}$ In this study, both the methanolic extract and morphine increased pain response latency, compared with the control group.

Pre-exposure to naloxone eliminated the analgesic effect of red algae extract and morphine, showing that the analgesic action of the extract may be dependent on endogenous opioid systems. ${ }^{41}$ The methanolic extract of L. caspica also demonstrated good potential in attenuating nociception observed using acetic acid, however the potential was less than that of morphine with naloxone. Furthermore, the methanolic extract of $L$. caspica reduced formalin-triggered inflammation maximally at the dose of $120 \mathrm{mg} / \mathrm{kg}$. The results were comparable with indomethacin, a nonselective COX inhibitor. ${ }^{42,43}$ The potential anti-inflammatory effects of phytoconstituents 
like oleanonic acid in the red algae have been shown in experimental models related with the activation of 5-lipoxygenase. ${ }^{44}$ The anti-inflammatory and analgesic activities of methanolic extract of L. caspica may partly be ascribed to the presence of bioactive compounds.

\section{Conclusion}

To conclude, the methanolic extract of $L$. caspica revealed significant antinociceptive activity in laboratory animals. The observed effects could be attributed to the presence of phytoconstituents like triterpenoid and flavonoid compounds. It is recommended that further studies are conducted to discover novel anti-inflammatory and antinociceptive compounds from active methanolic extract of L. caspica.

\section{Ethical Approval}

All animal experiments were done according to the NIH Guide for the Care and Use of Laboratory Animals (NIH Publications No. 80-23). All experiments were approved by the Animal Care and Ethics Committee of Islamic Azad University and approved with the code IR.IAU. RASHT.REC.

\section{Conflict of Interest Disclosure}

The authors declare no conflict of interests.

\section{Authors' Contribution}

KK: Supervision, concept, and design and manuscript writing; MR and SK: Data collection and analysis.

\section{Acknowledgment}

This manuscript was the result of a research project approved by Islamic Azad University of Lahijan. The authors appreciate the Research Deputy of the university.

\section{References}

1. De Oliveira L, Tschoeke DN, De Oliveira A S, et al. New insights on the terpenome of the Red Seaweed Laurencia dendroidea (Florideophyceae, Rhodophyta). Mar Drugs 2015; 13: 879-902. doi:10.3390/md13020879

2. Kumar Jha R, Zi-rong Xu. Biomedical compounds from marine organisms. Mar Drugs 2004; 2:123-146. doi: $10.3390 / \mathrm{md} 203123$

3. Smit A J. Medicinal and pharmaceutical uses of seaweed natural products: a review. J Appl Phycol 2004; 16:245-262. doi:10.1007/bf00003999

4. Lee JC, Hou MF, Huang HW, et al. Marine algal natural products with anti-oxidative, anti-inflammatory, and anticancer properties. Cancer Cell International 2013; 13:55. doi: 10.1186/1475-2867-13-55.

5. Schramm A, Matusik P, Osmenda G, Guzik TJ. Targeting NADPH oxidases in vascular pharmacology. Vasc Pharmacol 2012; 56:216-231. doi:10.1016/j. vph.2012.02.012

6. Rosanna DP, Salvatore C. Reactive oxygen species, inflammation, and lung diseases. Curr Pharm Des 2012;
18:3889-3900. doi:10.2174/138161212802083716

7. Kim YJ, Kim EH, Hahm KB. Oxidative stress in inflammation-based gastrointestinal tract diseases: challenges and opportunities. J Gastroenterol Hepatol 2012; 27:1004-1010. doi:10.1111/j.1440-1746.2012.07108.x

8. Abad MJ, Bedoya LM, Bermejo P: Natural marine antiinflammatory products. Mini Rev Med Chem 2008; 8:740754. doi: 10.2174/138955708784912148

9. Wang W, Wang SX, Guan HS. The antiviral activities and mechanisms of marine polysaccharides: an overview. Mar Drugs 2012; 10:2795-2816. doi: 10.3390/md10122795

10. D'Orazio N, Gammone MA, Gemello E, et al. Marine bioactive: pharmacological properties and potential applications an against inflammatory disease. Mar Drugs 2012; 10:812-833. doi: $10.3390 / m d 10040812$

11. Hansson GK. Inflammation, atherosclerosis, and coronary artery disease. N Engl J Med 2005; 352:1685-1695. doi: 10.1056/NEJMra043430

12. Fontenelle TPC, Lima GC, Mesquita JX, et al. Lectin obtained from the red seaweed Bryothamniontriquetrum: Secondary structure and anti-inflammatory activity in mice. Int J Biol Macromol 2018; 112: 1122-1130. doi. 10.1016/j.ijbiomac.2018.02.058

13. Fernandoa IPS, Nahb JW, You-Jin JeonY J. Potential anti-inflammatory natural products from marine algae. Environ Toxicol Pharmacol 2016; 48:22-30. doi. 10.1016/j. etap.2016.09.023

14. Jugutt BI. Cyclooxygenase inhibition and adverse remodeling during healing after myocardial infarction. Circulation 2007; 115:288-291. doi: 10.1161/ circulationaha.106.675306

15. Delgado NG, Vazquez AI, Sanchez $\mathrm{CH}$, et al. Antiinflammatory and antinociceptive activities of methanolic extract from red seaweed Dichotomaria obtusata. Braz J Pharm Sci 2013; 49:65-74. doi: 10.1590/S198482502013000100008

16. D’orazio N, Gammone MA, Gemello E, et al. Marine bio actives: pharmacological properties and potential applications against inflammatory diseases. Mar Drugs 2012; 10(4):812-833. doi: 10.3390/md10040812.

17. Coura CO, de Araujo IW, Vanderlei ES, et al. Antinociceptive and anti-inflammatory activities of sulphated polysaccharides from the red seaweed Gracilaria cornea. Basic Clin Pharmacol Toxicol. 2012; 110:335-341. doi: 10.1111/j.1742-7843.2011.00811.

18. Tanko Y, Mohammed A, Okasha MA, Umar AH, Magaji RA. Anti-nociceptive and anti-inflammatory activities of ethanol extract of Syzygium aromaticum flower bud in Wistar rats and mice. Afr J Tradit Complement Altern Med. 2008;5(2):209-212. doi:10.4314/ajtcam.v5i2.31275

19. 19 Wells ML, Potin P, Craigie JS, et al. Algae as nutritional and functional food sources: revisiting our understanding. J Appl Phycol. 2017;29(2):949-982. doi:10.1007/s10811016-0974-5

20. Topcu G, Aydogmus Z, Imre S, et al. Brominated sesquiterpenes from the red alga Laurencia obtusa. J Nat Prod 2003; 66:1505-1508. doi: 10.1021/np030176p.

21. Ji NY, Li XM, Ding LP, Wang BG. Two new aristolane sesquiterpenes from Laurencia similis. Chin Chem Lett 2007; 18:178-180. doi: 10.1016/j.cclet.2006.12.043. 
22. Afef Dellai A B, Syrine Laajili A, Valérie LE M, Jacques R, Abderrahman B. Antiproliferative activity and phenolics of the Mediterranean seaweed Laurencia obusta. Ind Crop Prod 2013; 47:252-255. doi: 10.1016/j.indcrop.2013.03.014.

23. Chatter R, Ben Othman R, Rabhi $S$, et al. In vivo and in vitro anti-inflammatory activity of neorogioltriol, a new diterpene extracted from the red algae Laurencia glandulifera. Mar Drugs 2011; 9:1293-1306. doi: 10.3390/ md9071293

24. Ayyad SE, Al-Footy KO, Alarif WM, et al. Bioactive C15 acetogenins from the red alga Laurencia obtusa. Chem Pharm Bull (Tokyo) 2011; 59:1294-1298. doi: 10.3390/ molecules 22050807

25. Sterrer W. Marine Fauna and Flora of Bermuda (A Systematic Guide to The Identification of Marine Organisms). New York: John Wiley; 1986.

26. Ainsworth EA, Gillespie KM. Estimation of total phenolic content and other oxidation substrates in plant tissues using Folin-Ciocalteu reagent. Nat Protoc. 2007;2(4):875877. doi: $10.1038 /$ nprot.2007.102

27. Schlede E, Mischke V, Roll R, Kayser D. A national validation study of the acute-toxic-class method as alternative to the LD50 test. Arch Toxicol 1992; 66: 455- 70. doi: 0.1007/bf01970670

28. Hunskaar S, Berge O G, Hole K. Dissociation between antinociceptive and anti-inflammatory effects of acetylsalicylic acid and indomethacin in the formalin test. Pain 1986; 25: 125-32. doi:10.1016/0304-3959(86)90014-x

29. Shang X, Wangc J, Li M, et al. Antinociceptive and anti-inflammatory activities of Phlomis umbrosa Turcz extract. Fitoterapia 2011; 82: 716-721. doi:10.1016/j. fitote.2011.03.001

30. Aoki M, Tsuji M, Takeda H, et al. Antidepressants enhance the antinociceptive effects of carbamazepine in the acetic acid-induced writhing test in mice. Eur J Pharmacol 2006; 550: 78-83. doi: 10.1016/j.ejphar.2006.08.049

31. Neelakandan Y, Venkatesan A. Antinociceptive and antiinflammatory effect of sulfated polysaccharide fractions from Sargassum wightii and Halophila ovalis in male Wistar rats. Indian J Pharmacol. 2016;48(5):562-570. doi:10.4103/0253-7613.190754

32. Bitencourt Fda S, Figueiredo JG, Mota MR, et al. Antinociceptive and anti-inflammatory effects of a mucin-binding agglutinin isolated from the red marine alga Hypnea cervicornis. Naunyn Schmiedebergs Arch Pharmacol 2008; 377:139-148. doi: 10.1007/s00210-0080262-2.
33. Silva LM, Lima V, Holanda ML, et al. Antinociceptive and anti-inflammatory activities of lectin from marine red alga Pterocladiella capillacea. Biol Pharm Bull 2010; 33:830-835. doi: 10.1248/bpb.33.830

34. EL Shoubaky GA, Abdel-Diam MM, Mansour MH, Salem EA. Isolation and identification of a flavone apigenin from marine red alga Acanthophora spicifera with antinociceptive and anti-inflammatory activities. J Exp Neurosci 2016; 10: 21-29. doi: 10.4137/JEN.S25096

35. Lee HJ, Dang HT, Kang GJ, et al. Two enone fatty acids isolated from Gracilaria verrucosa suppress the production of inflammatory mediators by down-regulating NFkappaB and STAT1 activity in lipopolysaccharide-stimulated RAW 264.7 cells. Arch Pharm Res 2009; 32:453-462. doi: 10.1007/s12272-009-1320-0

36. Saarto T, Wiffen PJ. Antidepressants for neuropathic pain: a Cochrane review. J Neurol Neurosurg Psychiatry 2010; 81:1372-3. doi: 0.1136/jnnp.2008.144964

37. Shabab T, Khanabdali R, Moghadamtousi SZ, Kadir HA, Mohan G. Neuroinflammation pathways: a general review. Int J Neurosci. 2017; 127:624-633. doi: 10.1080/00207454.2016.1212854

38. Ning C, Wang HD, Gao R, et al. Marine-derived protein kinase inhibitors for neuroinflammatory diseases. Biomed Eng Online. 2018; 17:46. doi: 10.1186/s12938-018-0477-5.

39. Montero L, del Pilar Sánchez-Camargo A, Ibáñez E, Gilbert-López B. Phenolic compounds from edible algae: bioactivity and health benefits. Curr Med Chem. 2018; 25:4808-4826. doi: 10.2174/0929867324666170523120101.

40. Fan X, Bai L, Zhu L, Yang L, Zhang X. Marine algae-derived bioactive peptides for human nutrition and health. J Agric Food Chem. 2014; 62:9211-9222. doi: 10.1021/jf502420h

41. Fernando IPS, Nah JW, Jeon YJ. Potential anti-inflammatory natural products from marine algae. Env. Toxicol Pharm. 2016; 48:22-30. doi: 10.1016/j.etap.2016.09.023

42. Barbalace MC, Malaguti M, Giusti L, Lucacchini A, Hrelia S, Angeloni C. Anti-inflammatory activities of marine algae in neurodegenerative diseases. Int J Mol Sci. 2019; 20(12):3061. doi: 10.3390/ijms20123061

43. Pangestuti R, Kim SK. Neuroprotective effects of marine algae. Mar. Drugs. 2011; 9:803-818. doi: 10.3390/ md9050803

44. Giner-Larza EM, Máñez S, Recio MC, et al. Oleanonic acid, a 3-oxotriterpene from Pistacia, inhibits leukotriene synthesis and has anti-inflammatory activity. Eur J Pharmacol. 2001;428(1):137-43. doi:10.1016/s00142999(01)01290-0 